\title{
Acetylcholine-Evoked Calcium Increases in Deiters' Cells of the Guinea Pig Cochlea Suggest $\alpha$ 9-Like Receptors
}

\author{
Takeshi Matsunobu, ${ }^{1,2}$ Jong Woo Chung, ${ }^{1,3}$ and Jochen Schacht ${ }^{1 \star}$ \\ ${ }^{1}$ Kresge Hearing Research Institute, University of Michigan, Ann Arbor, Michigan \\ ${ }^{2}$ Department of Otolaryngology, School of Medicine, Keio University, Tokyo, Japan \\ ${ }^{3}$ Department of Otolaryngology, Asan Medical Center, University of Ulsan, Seoul, Korea
}

The medial efferent system innervates outer hair cells in the organ of Corti. Neurotransmission at this synapse is mediated by acetylcholine (ACh) acting on nicotinic ACh receptors containing the $\alpha 9$ subunit. In addition to the sensory cells, the supporting cells of the mammalian cochlea also receive efferent innervation but the neurotransmitter(s) at these synapses are not known. We show slow transient increases of intracellular calcium evoked by ACh in isolated Deiters' cells of the guinea pig cochlea. The antagonists atropine, d-tubocurarine and strychnine blocked the ACheffect. Nicotine was an ineffective agonist. The pharmacologic profile and the kinetics of the calcium response suggest an $\alpha 9$-like ACh receptor on Deiters' cells similar but not identical to that on the outer hair cells. J. Neurosci. Res. 63:252-256, 2001. ๑ 2001 Wiley-Liss, Inc.

Key words: cholinergic receptors; inner ear; supporting cells; $\alpha 9$ subunit

The major neurotransmitter of the medial olivocochlear efferent system is acetylcholine (ACh; Bledsoe et al., 1988; Eybalin, 1993; Puel, 1995; Bobbin, 1996). The medial efferent neurons originate in the superior olivary complex (for review see Warr, 1992) and terminate primarily on outer hair cells in the cochlea. The ACh receptors on these sensory cells contain the $\alpha 9$ subunit, a subtype with unique pharmacologic properties (Erostegui et al., 1994; Elgoyhen et al., 1994). These properties include a characteristic block by atropine, curare and strychnine, and a high permeability to calcium (Katz et al., 2000 ) that is also seen in isolated outer hair cells (Doi and Ohmori, 1993).

Deiters' cells of the organ of Corti are in direct contact with the outer hair cells. They contain microfilaments and microtubules and have primarily been considered a structural reinforcement of the neurosensory epithelium. More recent speculation, however, links these cells to dynamic structural changes (Dulon, 1994; Flock et al., 1999) and calcium-based regulatory processes in the inner ear (Matsunobu and Schacht, 2000). Deiters' cells are innervated (Nadol and Burgess, 1994; Burgess et al., 1997; Fechner et al., 1998) yet the transmitters and recep- tors at these synapses are not known. Intracellular free calcium $\left[\mathrm{Ca}^{2+}\right]_{i}$ in Deiters' cells is regulated by ATP (Dulon et al., 1993) and nitric oxide (Matsunobu and Schacht, 2000). In the present study, we investigate the effect of ACh on $\left[\mathrm{Ca}^{2+}\right]_{i}$ in isolated Deiters' cells of the guinea pig cochlea and characterize the ACh effect pharmacologically

\section{MATERIALS AND METHODS}

\section{Materials and Animals}

Except where noted, all chemicals were purchased from Sigma (St. Louis, MO). Pigmented guinea pigs initially weighing 250-300 g were obtained from Murphy's Breeding Laboratories (Plainfield, NJ). The experimental protocols are in compliance with guidelines of the National Institutes of Health and Declarations of Helsinki and were approved by the University of Michigan's Committee on Use and Care of Animals. Animal care was under supervision of the University of Michigan's Unit for Laboratory Animal Medicine.

\section{Cell Preparation and Calcium Imaging}

Guinea pigs were anesthetized with $\mathrm{CO}_{2}$ and decapitated, the temporal bones were quickly removed and the bony wall of the cochlea was immediately opened. After detaching the stria vascularis and the tectorial membrane, the organ of Corti (mostly from the apical and middle turns) was microdissected from the spiral lamina. The dissected strips were incubated for $20 \mathrm{~min}$ in Hank's balanced salt solution (HBSS, Life Technologies, Grand Island, NY) additionally buffered with $5.0 \mathrm{mM}$ sodium HEPES to $\mathrm{pH} 7.4$ and its osmolality adjusted at $300 \pm 2 \mathrm{mOsm}$ with $\mathrm{NaCl}$ ) containing collagenase (Sigma type IV; final concentration, $1 \mathrm{mg} / \mathrm{ml}$ ). The strips were then transferred into a $50 \mu \mathrm{l}$ droplet of HBSS on a glass coverslip sealed in the middle of a perforated plastic Petri dish. The isolation procedure was com-

Contract grant sponsor: National Institutes of Deafness and Other Communication Disorders, NIH; Contract grant number: DC-02982.

^Correspondence to: Dr. Jochen Schacht, Kresge Hearing Research Institute, 1301 East Ann Street, Ann Arbor, MI 48109-0506.

E-mail: schacht@umich.edu

Received 7 August 2000; Revised 13 November 2000; Accepted 14 November 2000 
pleted by gentle influx and efflux of the tissue pieces through a micropipette. All experiments were conducted at room temperature.

One-mM stock solutions of the cell-permeant acetoxy methyl ester derivative of fluo-3, fluo-3/AM (Molecular Probes Inc., Eugene, OR) were prepared in dry dimethyl sulfoxide (DMSO) and stored below $0^{\circ} \mathrm{C}$. Deiters' cells were incubated for $30 \mathrm{~min}$ with $2 \mu \mathrm{M}$ fluo-3/AM in HBSS in a saturated humid chamber. Cells were finally carefully rinsed with HBSS.

Cells loaded with fluo-3 were observed with an inverted microscope (Leitz Fluovert FS; Leitz, Wetzlar, Germany) fitted with an epifluorescence system (ArcLamp HBO 100 W, a 450-490 nm band pass exciter filter, $510 \mathrm{~nm}$ dichroic mirror, and a $520 \mathrm{~nm}$ barrier filter for excitation and emission, respectively) and Nikon objectives. The excitation irradiance was reduced by neutral density filters to prevent photobleaching.

Cell fluorescence was monitored via a Silicon Intensified Target camera (SIT 66, Dage-MTI Inc., Michigan City, IN), and the recorded images were analyzed with Axon Workbench 2.1 software (Axon Instruments, Inc., Foster City, CA). Sixteen to 32 sequential frames were averaged and fluorescence intensity of the images was quantified by averaging the pixel radiance value of the entire cell.

Changes in $\left[\mathrm{Ca}^{2+}\right]_{i}$ were calculated by a single-excitation wavelength ratio method (Neher and Augustine, 1992). For each cell, the pre-stimulus fluorescence, $F_{0}$, and the fluorescence at a given time after the stimulus, $F_{t}$, were measured. The response is expressed as the ratio $F_{t} / F_{O}$ or as $F_{\max } / F_{O}$ for the maximal response.

\section{Application of Drugs}

The agonists ACh or nicotine were dissolved in HBSS and applied to the cells for $60 \mathrm{sec}$ via a glass pipette (Sterile Femtotips, Eppendorf Scientific, Westbury, NY) connected to a pressure puff ejector (PLI-100, Medical Systems Corp., Greenvale, NY). The pipette (opening, $0.5 \pm 0.2 \mu \mathrm{m}$ ) was held about $50 \mu \mathrm{m}$ away from the base of the cell. Preliminary experiments with fluorescent dyes showed that the pressure-ejected bolus (in the $\mathrm{nl}$ range) reached the cell within $1 \mathrm{sec}$. Concentrations of $\mathrm{ACh}$ or nicotine are stated as concentrations in the delivery pipette.

Atropine, d-tubocurarine or strychnine, dissolved in HBSS, pH 7.4, was applied to the bath $10 \mathrm{~min}$ before the injection of ACh. Five $\mu \mathrm{l}$ of a stock solution were added with a micropipette to the $50-\mu l$ droplet containing the cells.

\section{Data Analysis}

Changes in $\left[\mathrm{Ca}^{2+}\right]_{\mathrm{i}}$ were calculated by measuring the peak of the response above basal level. All values are presented as means \pm SEM. Differences between mean values were evaluated using ANOVA followed by Newman-Keul's as a post hoc test. A $P$ value of $<0.05$ was considered significant.

\section{RESULTS}

\section{Agonist-Induced Increase of Intracellular Calcium}

In isolates of cochlear cells, Deiters' cells were easily identified by their phalangeal processes (Fig. 1, arrow). They retained morphological integrity for approximately

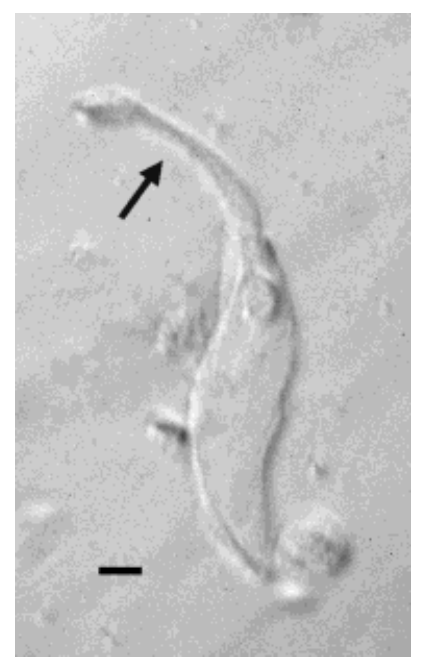

Fig. 1. An isolated Deiters' cell of the guinea pig cochlea. Deiters' cells were isolated as described in Materials and Methods and identified by their phalangeal processes (arrow). Scale bar $=10 \mu \mathrm{m}$.

4 hr post mortem as judged by their light microscopic appearance. All experiments reported here were conducted within 1 hr after cell isolation. Fluo-3 fluorescence was stable in resting cells, and an estimate of $\left[\mathrm{Ca}^{2+}\right]_{i}$ was made from a combined in vivo and in situ calibration as described previously (Dulon et al., 1990). $\left[\mathrm{Ca}^{2+}\right]_{i}$ at rest was approximately $55 \mathrm{nM}$. A puff of HBSS did not cause any significant changes in $\left[\mathrm{Ca}^{2+}\right]_{\mathrm{i}}$.

The injection of a bolus of ACh (1 mM solution of ACh in the delivery pipette) produced an increase of fluorescence in $44 \%(20 / 46)$ of the cells with a delay ranging from 20-100 sec (Fig. 2). After the maximum, fluorescence decreased with a half-life of approximately $60 \mathrm{sec}$, indicating calcium buffering or sequestering by the cell. A second application of ACh elicited a much attenuated response or none at all.

The amplitude of the calcium response depended on the ACh concentration (Fig. 3). $F_{\max } / F_{O}$ increased up to $1.68 \pm 0.10$ in responding cells with an $\mathrm{EC}_{50}$ of $30 \mu \mathrm{M}$. Because the bolus of ACh was diluted by the $50 \mu \mathrm{l}$ bath, the effective ACh concentrations at the cell can be estimated to be in the low micromolar range or less. The dose-response curve could be fitted well $\left(r^{2}=0.97\right)$ to a Hill plot yielding a Hill coefficient of 0.92 consistent with a 1:1 ratio of ACh receptor binding.

When $1 \mathrm{mM}$ nicotine was injected into the bath in the same manner (Fig. 4), only one of six cells responded $\left(F_{\max } / F_{O}=1.28\right)$ although $11 / 25(44 \%)$ reacted to $1 \mathrm{mM}$ acetylcholine in this experimental set. At $10 \mathrm{mM}$ nicotine, only two of ten cells responded and did so with a lower increase than seen with 0.1 or $1 \mathrm{mM} \mathrm{ACh}\left(F_{\max } / F_{O}=\right.$ $1.43 \pm 0.02)$

\section{Effects of Antagonists}

The pharmacology of the cholinergic response was further characterized by applying several antagonists (Fig. 




Fig. 2. Time course of ACh-evoked $\left[\mathrm{Ca}^{2+}\right]_{\mathrm{i}}$ transients. Acetylcholine was applied and $\left[\mathrm{Ca}^{2+}\right]_{\mathrm{i}}$ was determined as described in Materials and Methods. The curve represents a typical response of a Deiters' cell to a bolus application of $1 \mathrm{mM} \mathrm{ACh}$ (concentration in the delivery pipette). A second application elicited a significantly smaller response in some cells or none at all.

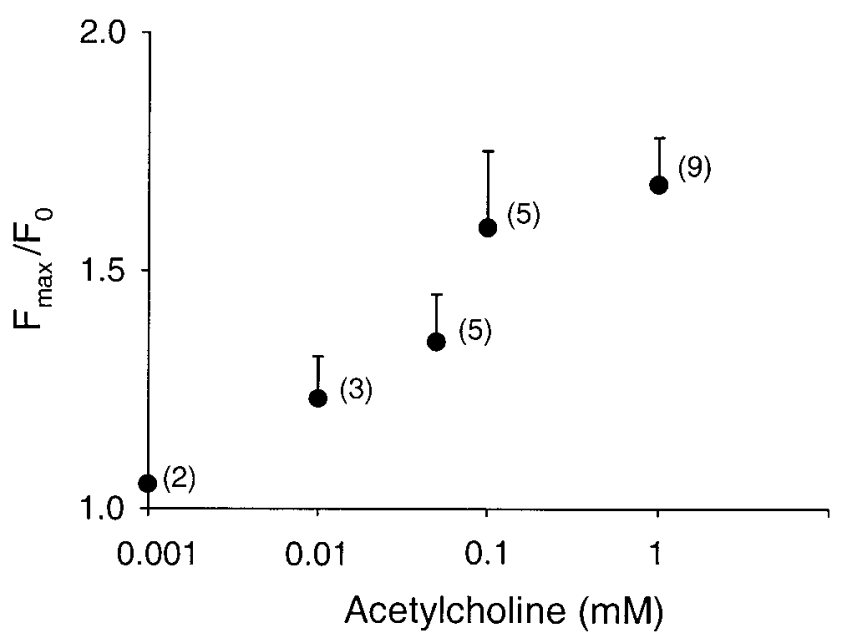

Fig. 3. Dose-response curve of ACh-evoked $\left[\mathrm{Ca}^{2+}\right]_{\mathrm{i}}$ increase. The concentration of $\mathrm{ACh}$ is given as its concentration in the delivery pipette. Values are means \pm SEM with sample size in parentheses. Responses are statistically significant for 0.1 and $1 \mathrm{mM} \mathrm{ACh}$.

5). Atropine, a classical antagonist of muscarinic receptors, attenuated the ACh-evoked transient increase of $\left[\mathrm{Ca}^{2+}\right]_{\mathrm{i}}$. At $10 \mu \mathrm{M}$ atropine, the peak was significantly decreased to $F_{\max } / F_{O}=1.17 \pm 0.04(\mathrm{n}=5, P<0.05)$ with $31 \%$ $(5 / 16)$ of the cells responding. Only one cell $(1 / 19)$ responded to ACh after pre-incubation with $50 \mu \mathrm{M}$ atropine.

The nicotinic antagonist d-tubocurarine $(1 \mu \mathrm{M})$ also suppressed the ACh-evoked calcium response. Thirtythree percent $(5 / 15)$ of the cells responded but the magnitude of the increase was significantly smaller $\left(F_{\max } / F_{0}=\right.$ $1.11 \pm 0.03 ; \mathrm{n}=5, P<0.05)$.

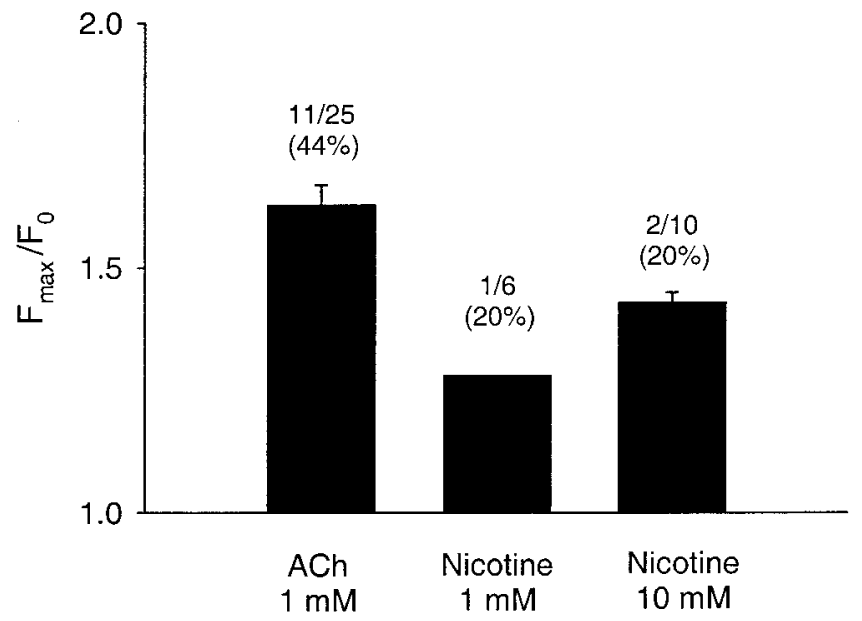

Fig. 4. Response of Deiters' cells to nicotine. ACh or nicotine was delivered as a $60-\mathrm{sec}$ bolus; concentrations are given as concentrations in the delivery pipette. The amplitude of the $\left[\mathrm{Ca}^{2+}\right]_{i}$ increase is calculated from the responding cells only. Data are mean \pm SEM with sample size in parentheses.

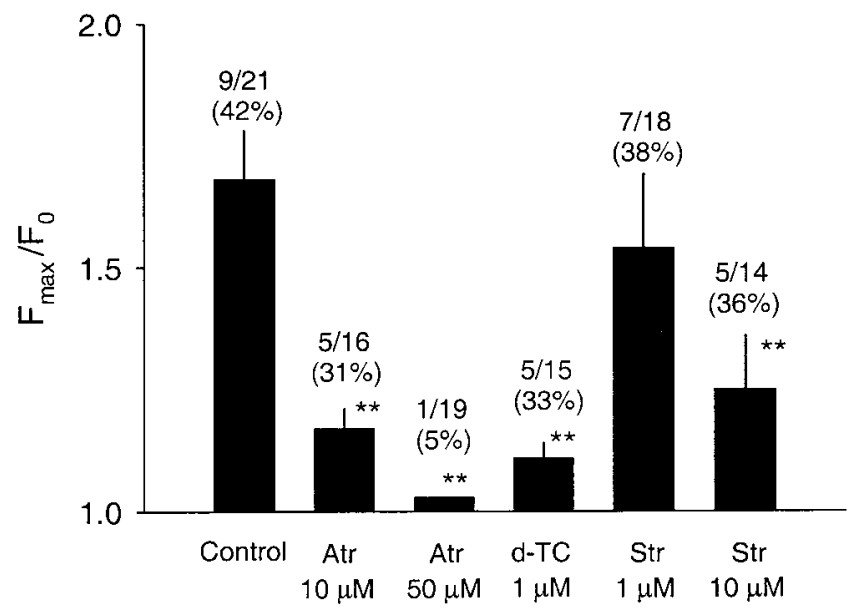

Fig. 5. Effect of cholinergic antagonists. All cells in this set received a $60 \mathrm{sec}$ bolus of $1 \mathrm{mM}$ ACh (concentration in the delivery pipette) in the absence or presence of antagonists. Antagonists were applied to the bath $10 \mathrm{~min}$ before ACh application. The amplitude of the $\left[\mathrm{Ca}^{2+}\right]_{\mathrm{i}}$ increase is calculated from the responding cells only. Data are mean \pm SEM with sample size in parentheses. Control, ACh in the absence of antagonists; Atr, ACh + atropine; d-TC, ACh + d-tubocurarine; Str, ACh + strychnine. ${ }^{\star} P<0.05$, compared to response in HBSS.

The alkaloid strychnine, classically used as a blocker of glycine-gated chloride channels, also acted as a dosedependent antagonist. After pretreatment with $1 \mu \mathrm{M}$ strychnine, $38 \%(7 / 18)$ of the cells still responded to ACh with an increase of calcium to $F_{\max } / F_{O}=1.54 \pm 0.15$ ( $n=7$; n.s.). Ten $\mu M$ strychnine significantly reduced the ACh response to an amplitude of $F_{\max } / F_{O}=1.25 \pm 0.10$ (n $=5, P<0.05)$, observed in $36 \%(5 / 14)$ of the cells. 


\section{DISCUSSION}

The results suggest the presence of an $\alpha$ 9-like receptor on Deiters' cells of the guinea pig cochlea. Although $\mathrm{ACh}$ is the major neurotransmitter released from efferent fibers in the cochlea (Bledsoe et al., 1988; Eybalin, 1993; Puel, 1995; Bobbin, 1996), this site of action is unexpected. It is the outer hair cells in the neurosensory epithelium of the organ of Corti that are considered the targets of the medial efferent innervation (Kimura and Wersäll, 1962; Spoendlin, 1966; Warr, 1992). Consistent with this view, outer hair cells possess ACh receptors that have been characterized pharmacologically, immunocytochemically and by in situ hybridization as containing the $\alpha 9$ subunit (Elgoyhen et al., 1994; Erostegui et al., 1994; Blanchet et al., 1996; Park et al., 1997; Luo et al., 1998; Morley et al., 1998; Vetter et al., 1999).

On the other hand, supporting cells in the organ of Corti (Deiters' and Hensen's cells) do receive efferent (Nadol and Burgess, 1994; Burgess et al., 1997) and possibly afferent innervation (Fechner et al., 1998). Deiters' cells contain purinergic P2Y and P2X receptors (Dulon et al., 1993; Dulon, 1995; Housley et al., 1999), and the nitric oxide/cyclic GMP pathway attenuates the ATPevoked increases of intracellular calcium (Matsunobu and Schacht, 2000). The demonstration of cholinergic responses makes ACh an additional transmitter candidate. Interestingly, the slow response to ACh contrasts to the fast response of these cells to ATP (Dulon et al., 1993; Matsunobu and Schacht, 2000) and is more reminiscent of the action of ACh in outer hair cells where calcium peaks $40 \mathrm{sec}$ after the onset of the stimulus (Doi and Ohmori, 1993). The response rate is also similar in both cell types with $38 \%$ of outer hair cells responding compared to $44 \%$ of Deiters' cells in our study.

The $\alpha 9$ subunit is part of an ionotropic ACh receptor that includes a calcium channel and shows specific pharmacologic features (Elgoyhen et al., 1994; Vetter et al., 1999; Rothlin et al., 1999; Katz et al., 2000). Important for a characterization of an $\alpha 9$ receptor are its block by both classical muscarinic and nicotinic antagonists, atropine and d-tubocurarine, respectively. In addition, the a9 receptor can be inhibited by strychnine (Elgoyhen et al., 1994; Rothlin et al., 1999) that is also a potent antagonist of the olivo-cochlear efferent system (Kujawa et al., 1992, 1994). All three antagonists attenuate the AChevoked calcium increases in Deiters' cells at concentrations comparable to those that attenuate ACh-evoked currents in isolated outer hair cells of the guinea pig (Doi and Ohmori, 1993; Erostegui et al., 1994). The correlation is, however, not strictly quantitative because d-tubocurare seems more effective in blocking calcium-responses at Deiters' cells than at outer hair cells (Doi and Ohmori, 1993).

This pharmacologic profile has to be interpreted with some caution because $\alpha 7$-subunits of the acetylcholine receptor may respond similarly, particularly because strychnine can block calcium channels non-specifically (Oyama et al., 1988). Both $\alpha 7$ and $\alpha 9$ subunits are ex- pressed in the organ of Corti of the rat (Morley et al., 1998). In the case of $\alpha 7$-subunits, however, nicotine should be a more potent agonist than ACh (Seguela et al., 1993; Gopalakrishnan et al., 1995) that it clearly is not at Deiters' cells. Therefore, the efficacy of agonists and antagonists suggests that Deiters' cells possess an $\alpha 9$-like ACh receptor. Although similar to that of outer hair cells, the slower kinetics of the response and the greater effectiveness of d-tubocurare at the Deiters' cells suggest that the receptors are not identical. Such a notion is also in agreement with the finding that Deiters' cells of the 4-day-old rat test negative for the $\alpha 9 \mathrm{ACh}$ receptor subunit (Glowatzki et al., 1995). It should be kept in mind, however, that the auditory periphery of the 4-day-old rat is a developing organ although our study uses the mature guinea pig.

The efferent system and ACh have well-defined actions on evoked cochlear potentials and are considered an important feedback on peripheral auditory processing (Mountain, 1980; Siegel and Kim, 1982; Kujawa et al., 1992, 1994). These effects are believed to be mediated through outer hair cells, the primary targets of medial efferent innervation. Deiters' cells are closely associated with outer hair cells and provide a scaffolding for the sensory neuroepithelium (Slepecky, 1996). Their phalangeal process attaches to the apex of an outer hair cell at the level of the reticular lamina although their basal end extends to the base of another outer hair cell. Calcium influx induces a small movement of the head of the phalangeal process and an increase of its stiffness (Dulon et al., 1993; Dulon, 1995), and overstimulation by sound can cause a contraction of the organ of Corti including the supporting cells (Friedberger et al., 1998). Neurotransmitter-induced changes of intracellular calcium in Deiters' cells may therefore contribute mechanical forces that influence the basilar membrane and its vibration.

\section{ACKNOWLEDGMENTS}

The authors thank Drs. Sanford Bledsoe, Colleen LePrell and David Dolan for helpful comments. This research was supported by program project grant DC02982 from the National Institutes of Deafness and Other Communication Disorders, National Institutes of Health.

\section{REFERENCES}

Blanchet C, Erostegui C, Sugasawa M, Dulon D. 1996. Acetylcholineinduced potassium current of guinea pig outer hair cells: its dependence on a calcium influx through nicotinic-like receptors. J Neurosci 16:25742584.

Bledsoe SC Jr, Bobbin RP, Puel JL. 1988. Neurotransmission in the inner ear. In: Jahn AF, Santos-Sacchi J, editors. Physiology of the ear. New York: Raven Press. p 385-406.

Bobbin RP. 1996. Chemical receptors on outer hair cells and their molecular mechanism. In: Berlin CI, editor. Hair cell and hearing aids. San Diego: Singular Press. p 29-55.

Burgess BJ, Adams JC, Nadol JB Jr. 1997. Morphologic evidence for innervation of Deiters' and Hensen's cells in the guinea pig. Hear Res 108:74-82. 
Doi T, Ohmori H. 1993. Acetylcholine increases intracellular $\mathrm{Ca}^{2+}$ concentration and hyperpolarizes the guinea-pig outer hair cell. Hear Res 67:179-188.

Dulon D, Zajic G, Schacht J. 1990. Increasing intracellular free calcium induces circumferential contractions in isolated outer hair cells. J Neurosci 10:1388-1397.

Dulon D, Moataz R, Mollard P. 1993. Characterization of $\mathrm{Ca}^{2+}$ signals generated by extracellular nucleotides in supporting cells of the organ of Corti. Cell Calcium 14:245-254.

Dulon D. 1995. $\mathrm{Ca}^{2+}$ signaling in Deiters' cells of the guinea-pig cochlea: Active process in supporting cells? In: Flock Å, Ottoson D, Ulfendahl M, editors. Active HEARING. New York: Pergamon. p 195-207.

Elgoyhen AB, Johnson DS, Boulter J, Vetter D, Heinemann S. 1994. $\alpha 9$ : an acetylcholine receptor with novel pharmacologic properties expressed in rat cochlear hair cells. Cell 79:705-715.

Erostegui C, Norris CH, Bobbin RP. 1994. In vitro pharmacologic characterization of a cholinergic receptor on outer hair cells. Hear Res 74:135-147.

Eybalin M. 1993. Neurotransmitters and neuromodulators of the mammalian cochlea. Physiol Reviews 73:309-373.

Fechner FP, Burgess BJ, Adams JC, Liberman MC, Nadol JB Jr. 1998. Dense innervation of Deiters and Hensen's cells persists after chronic deafferentation of guinea pig cochlea. J Comp Neurol 400:299-309.

Flock Å, Flock B, Fridberger A, Scarfone E, Ulfendahl M. 1999. Supporting cells contribute to control of hearing sensitivity. J Neurosci 19:44984507

Fridberger A, Flock Å, Ulfendahl M, Flock B. 1998. Acoustic overstimulation increases outer hair cell $\mathrm{Ca}^{2+}$ concentration and causes dynamic contraction of the hearing organ. Proc Natl Acad Sci USA 95:7127-7132.

Glowatzki E, Wild K, Brandle U, Fakler G, Fakler B, Zenner HP, Ruppersberg JP. 1995. Cell-specific expression of the alpha $9 \mathrm{n}$-ACh receptor subunit in auditory hair cells revealed by single-cell RT-PCR. Proc Royal Soc London B262:141-147.

Gopalakrishnan M, Buisson B, Touma E, Giordano T, Campbell JE, Hu IC, Donnelly-Roberts D, Arneric SP, Bertrand D, Sullivan JP. 1995. Stable expression and pharmacologic properties of the human alpha 7 nicotinic acetylcholine receptor. Eur J Pharmacol 290:237-246.

Housley GD, Kanjhan R, Raybould NP, Greenwood D, Salih SG, Jarlebark L, Burton D, Setz VC, Cannell MB, Soeller C, Christie DL, Usami S, Matsubara A, Yoshie H, Ryan AF, Thorne PR. 1999. Expression of the $\mathrm{P} 2 \mathrm{X}(2)$ receptor subunit of the ATP-gated ion channel in the cochlea: implications for sound transduction and auditory neurotransmission. J Neurosci 19:8377-8388.

Katz E, Verbitsky M, Rothlin CV, Vetter DE, Heinemann SF, Elgoyhen AB. 2000. High calcium permeability and calcium block of the $\alpha 9$ nicotinic acetylcholine receptor. Hear Res 141:117-128.

Kimura R, Wersäll J. 1962. Termination of the olivocochlear bundle in relation to the outer hair cells of the organ of Corti in guinea pig. Acta Otolaryngol (Stockholm) 55:11-32.

Kujawa SG, Glattke TJ, Fallon M, Bobbin RP. 1992. Intracochlear application of acetylcholine alters sound-induced mechanical events within the cochlear partition. Hear Res 61:106-116.
Kujawa SG, Glattke TJ, Fallon M, Bobbin RP. 1994. A nicotinic-like receptor mediates suppression of distortion product otoacoustic emissions by contralateral sound. Hear Res 74:122-134.

Luo L, Bennett T, Jung HH, Ryan A. 1998. Developmental expression of $\alpha 9$ acetylcholine receptor mRNA in the rat cochlea and vestibular inner ear. J Comp Neurol 393:320-331.

Matsunobu T, Schacht J. 2000. The nitric oxide/cyclic GMP pathway attenuates ATP-evoked intracellular calcium increase in supporting cells of the guinea pig cochlea. J Comp Neurol 423:452-461.

Morley BJ, Li HS, Hiel H, Drescher DG, Elgoyhen AB. 1998. Identification of the subunits of the nicotinic cholinergic receptors in the rat cochlea using RT-PCR and in situ hybridization. Mol Brain Res 53:7887.

Mountain DC. 1980. Changes in endolymphatic potential and crossed olivocochlear bundle stimulation alter cochlear mechanics. Science 210: 71-72.

Nadol JB Jr, Burgess BJ. 1994. Supranuclear efferent synapses on outer hair cells and Deiters' cells in the human organ of Corti. Hear Res 81:49-56.

Neher E, Augustine GJ. 1992. Calcium gradients and buffers in bovine chromaffin cells. J Physiol 450:273-301.

Oyama Y, Akaike N, Carpenter DO. 1988. Strychnine decreases the voltage-dependent $\mathrm{Ca}^{2+}$ current of both Aplysia and frog ganglion neurons. Cell Mol Neurobiol 8:307-314.

Park HJ, Niedzielski AS, Wenthold RJ. 1997. Expression of the nicotinic acetylcholine receptor subunit, $\alpha 9$, in the guinea pig cochlea. Hear Res 112:95-105.

Puel JL. 1995. Chemical synaptic transmission in the cochlea Prog Neurobiol 47:449-476.

Rothlin CV, Katz E, Verbitsky M, Elgoyhen AB. 1999. The $\alpha 9$ nicotinic acetylcholine receptor shares pharmacologic properties with type A $\gamma$-aminobutyric acid, glycine, and type 3 serotonin receptors. Mol Pharmacol 55:248-254

Seguela P, Wadiche J, Dineley-Miller K, Dani JA, Patrick JW. 1993. Molecular cloning, functional properties, and distribution of rat brain alpha 7: a nicotinic cation channel highly permeable to calcium. J Neurosci 13:596-604.

Siegel JH, Kim DO. 1982. Efferent neural control of cochlear mechanics. Olivocochlear bundle stimulation affects cochlear biomechanical nonlinearity. Hear Res 6:171-182.

Slepecky NB. 1996. Structure of the mammalian cochlea. In: Dallos P, Popper AN, Fay RR, editors. The cochlea. New York: Springer. p 44-129.

Spoendlin H. 1966. The organization of the cochlear receptor. Adv Otorhinolaryngol 13:1-227.

Vetter DE, Liberman MC, Mann J, Barhanin J, Boulter J, Brown MC, Saffiote-Kolman J, Heinemann SF, Elgoyhen AB. 1999. Role of $\alpha 9$ nicotinic ACh receptor subunits in the development and function of cochlear efferent innervation. Neuroanatomy 23:93-103.

Warr WB. 1992. Organization of olivocochlear efferent systems in mammals. In: Webster DB, Popper AN, Fay RR, editors. Mammalian auditory pathway: neuroanatomy. New York: Springer-Verlag. p 410-448. 